\title{
Born-global: The case of four Vietnamese SMEs
}

\author{
Mai Thi Thanh Thai $\cdot$ Li Choy Chong
}

Published online: 23 April 2008

(C) Springer Science + Business Media, LLC 2008

\begin{abstract}
Despite the fact that many firms in a wide range of industries in various countries internationalize at or near inception, research on factors leading to the formation of born-globals has been limited to firms from advanced, open economies. In order to give a voice to the phenomenon of Vietnamese founding born-globals, we conducted an exploratory, multiple-case study. Three findings of this study are: (1) the major driver to the formation of Vietnamese born-globals is the entrepreneurs' leadership desire together with the need for short-term profits; (2) their choice of internationalization mode is influenced by market conditions as well as the internationalization degree of the industries in which they find their business opportunities; and (3) the reason why other motivators found in earlier studies do not apply lies in the peculiarity of the Vietnam context.
\end{abstract}

Keywords Born-global · International entrepreneurship · Internationalization · Vietnamese SMEs

\section{Introduction}

For centuries, there have been firms that engaged in significant international activities shortly after being established (Oviatt and McDougall 2005), but research on this phenomenon only began in the late 1980s after the prevalence of such firms

\footnotetext{
M. T. T. Thai $(\bowtie)$

University of St. Gallen, Rue du Simplon 11, 1700 Fribourg, Switzerland e-mail: mai.thai@maithai.org

L. C. Chong

University of St. Gallen, Dufourstrasse 40a, 9000 St. Gallen, Switzerland e-mail: li-choy.chong@unisg.ch 
had been reported in popular business presses. Since then, this phenomenon has been researched under several terms. Examples are "global start-up" (Oviatt and McDougall 1995; Baughn and Neupert 2003; Johnson 2004), "instant exporter" (McAuley 1999), "instant global entrepreneurship" (Katz et al. 2003), "borninternational" (Kundu and Katz 2003), "international new venture" (McDougall 1994; Oviatt and McDougall 1994; Zahra 2005; etc.), and "born-global" (Knight and Cavusgil 1996; Madsen and Servais 1997; OECD 1997; Moen and Servais 2002; Räisänen 2003; Sharma and Blomstermo 2003; Rialp et al. 2005; Knight and Cavusgil 2005; etc.). These studies show that firms in a wide range of industries from various countries are internationalizing rapidly, that many are doing so soon after they are founded, and that the phenomenon does not seem to be limited to certain technologies or to particular sectors of the economy. For the sake of convenience, we refer to this phenomenon as "born-global", as this term appears most frequently in the current body of research literature. To be consistent with previous studies, we consider firms that start to internationalize within 2 years after inception to be born-global. It should be noted that internationalization can happen in either direction (inward or outward).

The fact that born-globals are appearing worldwide in large numbers (Knight and Cavusgil 2005) has triggered a growing interest in understanding the factors that lead to the early internationalization of young firms (Zahra 2005). To date, research on this phenomenon has tended to focus on firms from developed countries, so one may wonder if findings from such research are applicable to firms from developing countries. Vietnam is an interesting case as it is experiencing a transitional period from a closed centralized economy to a market-oriented one, and many Vietnamese firms are able to internationalize at or shortly after inception, while facing constraints that firms from developed countries do not encounter.

What can be learned from a study of these firms? Why do they choose to internationalize early? Why is it that certain motivators listed in the existing literature do not apply to these firms? This case study is designed to address these questions.

\section{Literature review}

Since a number of key internal and external driving forces behind the observable emergence of born-globals have been addressed in earlier studies, we conducted a comprehensive literature review to identify what motivators have been uncovered by the existing literature. The idea was to put that list into the context of Vietnam to find out what is applicable and what is not and then to seek an explanation for this. After screening the literature on born-globals published since the late 1980s, we came up with a long list of motivators. To make this list manageable, we categorized them. The result was a theoretically developed conceptual framework on four dimensions of analysis: founder/manager characteristics, firm resources and capabilities, industry structure and attributes, and socio-economic infrastructure (see Fig. 1). Our classification of push/pull forces is similar to Etemad's (2004). We will discuss each dimension in detail and provide a summary of factors leading to born-global formation (see Table 1) at the end of this section. 


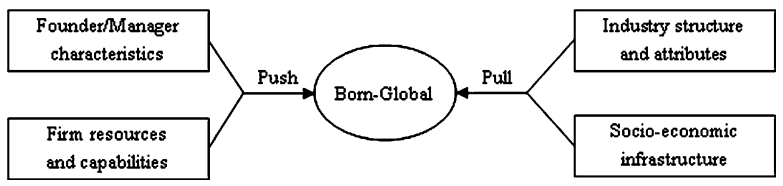

Fig. 1 Factors influencing the formation of born-global firms

\section{Firm resources and capabilities}

The development of resources, which are determined during the establishment phase in support of international market competitiveness, may be regarded as the key issue (Moen and Servais 2002). Born-global firms possess superior international market knowledge before their first foreign market entry (Sharma and Blomstermo 2003) or

Table 1 Summary of expected motivators

\begin{tabular}{|c|c|c|}
\hline Dimension & Expected motivators & \\
\hline \multirow{6}{*}{$\begin{array}{l}\text { Firm resources } \\
\text { and capabilities }\end{array}$} & Size & Relatively bigger size in terms of number of employees \\
\hline & $\begin{array}{l}\text { International market } \\
\text { knowledge }\end{array}$ & $\begin{array}{l}\text { Founders and/or employees have superior international } \\
\text { market knowledge than those of other firms }\end{array}$ \\
\hline & Product & Unique product \\
\hline & Technology & High technological innovativeness \\
\hline & $\begin{array}{l}\text { Entrepreneurship } \\
\text { orientation }\end{array}$ & $\begin{array}{l}\text { High entrepreneurship orientation (i.e., having autonomy } \\
\text { and high-risk preference as well as being innovative, pro- } \\
\text { active, and competitively aggressive) }\end{array}$ \\
\hline & Network & $\begin{array}{l}\text { Access to international networks of distributors, } \\
\text { subcontractors, buyers, sellers, and so on }\end{array}$ \\
\hline \multirow{7}{*}{$\begin{array}{l}\text { Founder/manager } \\
\text { characteristics }\end{array}$} & Age of the founder(s) & Young age \\
\hline & Education level & University/college education level \\
\hline & $\begin{array}{l}\text { Experience in founding } \\
\text { businesses }\end{array}$ & Some experience in founding businesses \\
\hline & $\begin{array}{l}\text { Industry and technical } \\
\text { experience }\end{array}$ & $\begin{array}{l}\text { Substantial industry and technical experience resulted } \\
\text { from previous business experience }\end{array}$ \\
\hline & International experience & $\begin{array}{l}\text { Significant international experience resulted from actual } \\
\text { business activities in foreign countries }\end{array}$ \\
\hline & Network & Having personal and business network that is international \\
\hline & $\begin{array}{l}\text { Entrepreneurial } \\
\text { inclination and global } \\
\text { vision }\end{array}$ & $\begin{array}{l}\text { Strong entrepreneurial inclination with high global vision } \\
\text { (geocentric orientation with positive attitude toward } \\
\text { international activities as a result of perception of low } \\
\text { risks) }\end{array}$ \\
\hline \multirow{3}{*}{$\begin{array}{l}\text { Industry structure } \\
\text { and attributes }\end{array}$} & Buyer preference & Homogenized buyer preference \\
\hline & Market condition & $\begin{array}{l}\text { Favorable market condition (in both demand and supply } \\
\text { sides) of the firm's market niche }\end{array}$ \\
\hline & Industry pressure & $\begin{array}{l}\text { High pressure resulted from the industry's degree of } \\
\text { internationalization }\end{array}$ \\
\hline \multirow[t]{7}{*}{$\begin{array}{l}\text { Socio-economic } \\
\text { infrastructure }\end{array}$} & $\begin{array}{l}\text { Information and } \\
\text { communication } \\
\text { technology }\end{array}$ & Advance in information and communication technologies \\
\hline & Production method & Advance in production methods \\
\hline & Transportation & Cheaper and more convenient transportation \\
\hline & Logistics & Better international logistics \\
\hline & $\begin{array}{l}\text { Trade and investment } \\
\text { barriers }\end{array}$ & $\begin{array}{l}\text { Reduction of trade and investment barriers as a result of } \\
\text { international economic integration }\end{array}$ \\
\hline & Financial market & Advance in financial market \\
\hline & Investment capital & Access to international investment capital \\
\hline
\end{tabular}


even at inception (Rialp et al. 2005). The knowledge is that of not only the top managers but also the staff, so firm size may be an important factor. Bloodgood et al. (1996) noted that firms with a greater number of employees may have access to a greater wealth of knowledge of international experience not reflected in top management international experience, that firms with a greater number of top managers experienced in international markets realize international aspirations more readily than those with fewer such managers, and that those ventures that are bigger at the outset and pursue product differentiation initially operate on a more fully internationalized basis. However, the size should not be too large so that the firms can enjoy advantages such as quicker response time, flexibility, adaptability, etc. that enable them to succeed in their early international endeavors (Knight and Cavusgil 1996).

Another important resource is firm advantage through product differentiation, leading-edge technology products, technological innovativeness, and quality leadership (Rialp et al. 2005). Born-global firms see themselves as owning or possessing a source of competitive advantage in foreign markets by way of their expertise, unique product features, lower price, better technical service, or a combination thereof (Evangelista 2005). They internationalize early in order to exploit their distinctive competence or feature-e.g., when they perceive their products to be especially unique (Bloodgood et al. 1996).

Even more critical in the birth of born-globals is international entrepreneurial orientation since it is an important driver of several important parameters such as internationalization preparation, strategic competence, and technology acquisition (Knight 2001). Entrepreneurship orientation represents autonomy, innovativeness, risk taking, pro-activeness, and competitive aggressiveness, all of which may be present when a firm engages in a new entry (Lumpkin and Dess 1996). Autonomy refers to the independent action of an individual or a team in bringing forth an idea or a vision and carrying it through to completion. Innovativeness reflects a firm's tendency to engage in and support new ideas, novelty, experimentation, and creative processes that may result in new products, services, or technological processes. Through innovative activities, firms that become born-global often develop particular types of knowledge, which drives the development of organizational capabilities needed for early internationalization and superior performance in diverse international markets for innovative activities, as these activities can facilitate the opening of new markets and a reinvention of operations to serve those markets optimally (Knight and Cavusgil 2004). Risk taking reflects the propensity to devote resources to projects that entail a substantial possibility of failure but also chances for high returns. Pro-activeness means acting in anticipation of future problems, needs, or changes and implies taking the initiative, aggressively pursuing ventures, and being at the forefront of efforts to shape the environment in ways that benefit the firm. It suggests a forward-looking perspective, accompanied by innovative or newventuring activity. Finally, competitive aggressiveness refers to the firm's tendency to challenge its competitors intensely and directly in order to outperform them in the marketplace. An aggressive stance and intense competition are critical to the survival and success of new entrants because new ventures are much more likely to fail than established businesses. In short, firms with an entrepreneurial orientation engage in product market innovations, undertake relatively risky ventures, initiate pro-active innovations, and take an aggressive stance (Morris and Kuratko 2002). 
And last but not least, access to international networks such as distributors, subcontractors, buyers, and sellers is a key resource of born-globals (Knight and Cavusgil 1996) during international preparation and technology acquisition, which are strong antecedents to international strategic competence (Knight 2001). These firms can particularly benefit from their partners' experiential knowledge in multiple markets, instead of slowly accumulating the knowledge themselves on a country-bycountry basis. For example, if firms want to internationalize quickly, they can use intermediaries to expedite their access to foreign markets (Burgel and Murray 2000). For born-global firms to enjoy a rapid and pro-active approach, the networks must be adequately extensive to enable good global reach and be created rapidly to support exposure to multiple markets (Chetty and Campbell-Hunt 2004; Sharma and Blomstermo 2003).

\section{Founder/manager characteristics}

Founder/manager characteristics, including demographic factors (e.g., age, gender, education, and prior experiences) and psychological factors (e.g., personality, attitudes, needs, and traits), play important roles in new venture creation (Shook et al. 2003) and influence the outcomes of the firm (Hambrick and Mason 1984). They determine firms' diversification (Michel and Hambrick 1992), export orientation (Dichtl et al. 1990), and international expansion (Kobrin 1994). Indeed, they influence the internationalization process of the firm (Bilkey 1978; Reid 1981).

The gestalt of managers' objective and experiential knowledge drives internationalization (Sullivan and Bauerschmidt 1990). Born-global firms are formed when entrepreneurs see opportunities for earning high returns by establishing businesses operating across national borders. They are able to see the opportunities while others do not because they possess competencies that are unique to them (McDougall 1994). Simpson and Kujawa (1974) found education to be a significant variable affecting and differentiating the responses of exporters and non-exporters to unsolicited orders from foreign customers, and they considered college and university education to be an important factor in the positive export decision. This implies that the higher the education level entrepreneurs have, the more likely they are to recognize international business opportunities. Besides education, previous industry and venture-founding experience stand out as important to the founding of the firms. Previous industry experience familiarize the founders with industry conditions, especially concerning existing products in the market and the needs of clients, while previous technical experience is important in developing a new venture's first product, which is crucial to international entry. Thus, they are positively correlated to the likelihood of creating a successful born-global firm (Evangelista 2005).

While an entrepreneur's education, training, and previous technical experience provide the expertise or capability required to develop initial and future products, they may not lead him/her to form an international venture. McDougall (McDougall et al. 2003) argued that the entrepreneur's international experience - rather than technical or marketing experience-plays an important role in the internationalization of new ventures, which do not benefit from organizational experience simply because they are new. International experience is the amount of experience accumulated in an international environment, not from mere exposure to the 
international arena. Roth (1995) posited that managers are more likely to develop a deeper understanding when they have been posted to other countries or are required to spend considerable time overseas than domestic managers who are responsible for overseas functions, suggesting that it is the experiential aspect of assignments that is of value, not non-experiential exposure through responsibility for international functions. The founders' international experience is a source of prior knowledge that helps them identify foreign market opportunities and also gives them the confidence to exploit these opportunities (Evangelista 2005). Hence, it is not unexpected that born-globals' founders often have extensive experience in relevant international markets (Rialp et al. 2005). Many researchers claim that this experience usually plays a crucial role in the founding process itself and/or in increasing the firm's speed of learning and internationalization, while reducing the psychic distance to specific markets (Oviatt and McDougall 1995; Bloodgood et al. 1996; Oviatt and McDougall 1997; Madsen and Servais 1997; Andersson and Wictor 2003).

It is not only the founders but also other people in the top management team that can influence the firm's involvement in international activities. Oviatt and McDougall (1997) argued that the international business experience most likely to influence the international commitment decisions of an international new venture is that of its top managers. Sambharya's (1996) study reveals that a higher proportion of managers with international experience in the top management team is significantly related to the stronger international presence and posture of the firm. Reuber and Fischer (1997) also attributed the firm's degree of internationalization to its top management team's international experience, arguing that internationally experienced management teams have a greater propensity to develop foreign strategic partners and to speed up foreign sales after start-up. Moreover, Bloodgood (Bloodgood et al. 1996) considered international experience of the venture's officers to be associated with the extent of international operations. However, Rialp's study (Rialp et al. 2005) shows a different picture. He found that there is little difference among born-global firms and gradual firms in the computer industry regarding international experience and knowledge previously accumulated by their key founders and managers. This indicates that other factors must come into play.

Prior occupational socialization, continued contact with external occupational reference groups, and extra-organizational linkages expose entrepreneurs to additional information as well as contacts with foreign sources and are likely to enhance their ability to discriminate and evaluate foreign market stimuli (Reid 1981; Evangelista 2005). Therefore, what is crucial to early, rapid, and successful global market reach is the use of both personal and business networks at the local and international level (Rialp et al. 2005). These networks can be formal or informal (Knight and Cavusgil 1996) and used in both formal and planned ways (McAuley 1999). Contacts and connections may compensate for the firm's lack of international experience (Evangelista 2005). Research shows them to be linked to the establishment of international new ventures (Ibeh 2003; McDougall et al. 2003). However, some born-global firms are established without the founders being involved in any international network (Rasmussen et al. 2000).

Managerial attitude, vision, and orientation are also critical in the firm's decision to internationalize (Reid 1981; Roberts and Senturia 1996; Moen 2002). Entrepreneurs may be ethnocentric (home-country oriented-i.e., having an attitude towards 
foreign cultures whereby employees and practices within the foreign market are believed to be inferior to those of the domestic market), polycentric (host-country oriented-i.e., having an attitude that cultures of various countries are different and that foreigners are difficult to understand and should be left alone as long as their work is profitable), or geocentric (world oriented-i.e., having an attitude that there are global similarities in both cultures and markets) (Perlmutter 1969). Such differences in centricities are caused by such factors as age (Pinney 1970), type and level of education, foreign nationality, ability to speak foreign languages, extent of foreign travel as well as other factors (Reid 1981). They color the perceptions which influence managers' assessment of several important external environment variables and reflect their preferences for the development of international organizations as well as the choice of strategies and the method for their implementation (Calof and Beamish 1994). Managers who perceive higher levels of risk are less likely to lead the firm into international markets than managers who perceive lower levels of risk (Simpson and Kujawa 1974). Indeed, managers' cognitive perspectives affect the international strategic capabilities of the firm and the willingness to expand the firm's activities into international markets (Bartlett and Ghosbal 1989) since they determine whether the managers can make sense of changing international market opportunities and respond to them (Murtha et al. 1998). In other words, entrepreneurs may equally desire to engage in international activities, but some are more likely than others to engage in such activities. Numerous studies listed in Harveston's (2000) paper report that managers with more positive attitudes toward international activities are more likely to engage in international activities. So bornglobal firms are likely to be formed by entrepreneurs with a strong international outlook who see the world as their marketplace (Knight et al. 2000). These founders do not adopt a strong domestic focus but rather perceive the entire world as one (Rialp et al. 2005). Compared to managers of other firms, they have a strong entrepreneurial inclination with a higher global vision and a more dedicated commitment to early internationalization efforts and challenges (Andersson and Wictor 2003; Evangelista 2005). These factors enable them to devise a collection of capabilities at the strategy and organizational-culture levels of the firm that give rise to an early adoption of internationalization and success in a broad range of foreign markets (Knight and Cavusgil 2004).

Industry structure and attributes

Several researchers have noted that international markets are becoming increasingly homogeneous (Levitt 1983; Hedlund and Kverneland 1985; Manalova 2003) with some industries almost requiring international operations (Burrill and Almassey 1993). The fact that the preferences of buyers around the world are being homogenized can substantially reduce the transactions costs of foreign market expansion as it enables firms to simplify their product development and positioning in foreign markets through international sourcing, production, and marketing as well as cross-border alliances for product development and distribution, etc. (Knight and Cavusgil 2004). Oviatt and McDougall's (1995) study suggests that the current and increasingly global nature of demand in many markets constitutes one of the main forces encouraging the formation of global start-ups.

Springer 
Niche markets created by changed consumer preferences have become an important source of opportunities for small firms, which are usually swifter than their larger competitors to adapt product offerings to meet emerging market needs (Rennie 1993). With the globalization of markets, growing demand among consumers in mature economies for specialized or customized products, and increasing worldwide competition from large multinationals, many smaller firms may have no choice but to specialize in the supplying of products that occupy relatively narrow global niches (Knight and Cavusgil 1996). Furthermore, global integration pressures necessitate worldwide resource deployments (Ghoshal 1987), so firms serving global market niches that have small cross-national segments of customers who are similar in terms of tastes, preferences, and buying power face strong industry pressures for the global integration of their resources (McDougall and Oviatt 1996).

Industry pressure can drive firms into foreign markets (Porter 1990). Accelerated internationalization now seems to be a worldwide phenomenon in many industries (Oviatt and McDougall 1997). If firms operate in a dynamic international environment, they are forced to adapt and innovate much more quickly than usual. Thus born-globals manifest an international strategy that is particularly well adapted to the emergence of global markets and global competition (Rialp et al. 2005). It may be that the rapid globalization of markets requires certain firms to compete internationally virtually from the outset (Bloodgood et al. 1996).

Evangelista (2005) postulated that some of the most influential environmental factors affecting the founding of internationally oriented ventures are a hostile domestic market (i.e., small, mature, highly competitive, and/or lacking support from government) and large and attractive foreign markets. If small firms possess an entrepreneurial orientation replete with the appropriate antecedent attributes, they are more likely to go international when faced with hostile operating environments (Ibeh 2003). On the other hand, if a large number of a venture's competitors and customers are international, the entrepreneurs are more likely to consider entry into foreign markets (Oviatt and McDougall 1997). This was confirmed by Andersson's (2002) study, which argues that, while a firm's own ambition can be to remain firmly positioned in one region, the result can be an increased internationalization due to the strong links to internationalizing suppliers, buyers, and competitors/partners. The author found that when a firm's main suppliers and/or buyers internationalize, the firm is pulled out into new national markets, too. At the same time, its strategic alliances' internationalization process can lead the firm to a higher degree of both indirect and direct international extension. On the other hand, the firm can defend its position by internationalizing in response to its competitors' concurrent internationalization efforts. Therefore, it is not surprising to see that born-global firms are more prevalent in industries characterized by a high degree of global integration (McDougall et al. 2003). Other industrial factors such as industry age and growth rate are also important drivers to the emergence of small multinationals (Andersson and Wictor 2003; Manalova 2003). For instance, the younger the global industry, the lower the barriers to entry; the higher the growth rate, the more opportunities for new entrants.

In short, industry characteristics play a significant role in the international development of a firm (Boter and Holmquist 1996; Manalova 2003). It has even been argued that industry characteristics are more important than the firm's nationality in its early internationalization (Boter and Holmquist 1996). 


\section{Socio-economic infrastructure}

In today's global economy, the means of internationalization knowledge, technology, tools, facilitating institutions, etc. have become more accessible to all firms (Knight and Cavusgil 1996). The burgeoning capacity of communications technologies has helped firms acquire knowledge, develop strategies, and maintain relationships to assist them in internationalizing early and accelerating the process (Chetty and Campbell-Hunt 2004). In fact, increases in efficiency due to advances in information and communications technologies, production methods, transportation, and international logistics have decreased the costs of international business and lifted barriers that previously prevented small firms from significantly participating in international markets (e.g., small size, lack of substantial tangible resources, and the inability to access costly information). Information technology and the Internet are liberating forces that permanently alter the landscape of international trade. With electronic process technology, small firms are now able to compete with larger firms on cost, quality, and flexibility. In addition, using the latest telecommunication and computer technology enables firms of any size to manage business systems that extend beyond their own boundaries (Rennie 1993).

While technology helps minimize location disadvantages (Evangelista 2005), the constant and systematic reduction of trade and investment barriers, as well as the increase of human capital mobility as a result of the ongoing development of international trade agreements and free trade areas (such as the Association of Southeast Asian Nations, the North American Free Trade Agreement, the AsiaPacific Economic Co-operation Forum, the European Union, and so forth, create good conditions for businesses to engage in international activities. This shift in international trade conditions has resulted in an increasing number of firms that are international from their inception (Aspelund and Moen 2001).

Concurrently, financial markets have become international, which means that entrepreneurs in any country may seek financial sources all over the world (Madsen and Servais 1997). Oviatt and McDougall's interviews with US-based global startups revealed that these firms were able to seek investment from other countries and even considered non-US investors to be more appropriate, as they believed that these investors were more patient than Americans and had longer investment horizons. This increased availability of international financing opportunities can certainly facilitate new ventures' international development efforts.

Overall, improvements in socio-economic infrastructure facilitate the widespread emergence of born-global firms (Knight and Cavusgil 2005). However, these environmental factors alone are not sufficient for an understanding of the bornglobal phenomenon as born-global firms are found in the same socio-economic environment as traditional companies (Andersson and Wictor 2003).

\section{Methodology}

Since most of the current literature on born-globals has been developed from samples taken from open and developed countries, we wanted to find out if the motivators listed in the literature apply to Vietnamese small- and medium-sized 
enterprises (SMEs) or not, and when certain factors were found not to apply, we wanted to know why. The first aim may be achieved by surveys, but Vietnamese businesspeople are notably reluctant to complete questionnaires, and there is a typical lack of published information. As a Vietnamese, born and raised in Vietnam, with years of working in the newspaper business, the first author knows that Vietnamese businesspeople are only likely to answer questionnaires if the questions come from government institutions. Nevertheless, they are open to people they trust and are willing to talk with researchers with good references from people within their business networks. Therefore, researchers without an affiliation to the Vietnamese government like us find it too hard to locate an unbiased sampling frame for a survey because we usually have to rely on relationships. Bell et al. (2004) and Carson et al. (1995) shared our views. On the other hand, it has been well argued in the existing literature that a case study method is appropriate "when a 'how' or 'why' question is being asked about a contemporary set of events over which the investigator has little or no control" (Yin 2003). In short, a case study method can help us meet both aims. Indeed, our choice of the case study method is justified for four reasons: (1) our aim is to explore the phenomenon since there were no earlier studies on factors leading to the formation of Vietnamese born-globals; (2) our research questions focus on the WHY; (3) the phenomenon is contemporary; and (4) we do not have control over the behavioral events.

Our case selection was based on theoretical considerations because in a case study the random selection of cases is neither necessary nor preferable, and extreme examples are most appropriate when seeking to extend theory (Eisenhardt 1989). The first consideration was the type of firm. Despite the fact that born-globals are generally defined as firms that internationalize at or near inception, and internationalization can be inward, ${ }^{1}$ most studies on born-globals have been done on exporters. To address this gap, we included importers in our case selection. The second consideration is replication logic. After the pilot case had been analyzed, we chose more cases for literal replication, which could explain the conditions under which Vietnamese entrepreneurs are likely to establish born-globals. We reached theoretical saturation point after four cases. It should be noted that we selected the first case, the pilot case, for convenience, access, and geographic proximity (Yin 2003). The founder of the first case is actually a long-time friend of the first author, and he is now a professor of entrepreneurship at a university in the US. Our relationship and his understanding of the literature allowed for in-depth interviews in which we discussed the phenomenon from both theoretical and empirical perspectives. The considerable insight from this pilot study enabled us to design better questions to ask in subsequent cases.

Following the recommendations of Yin (2003), we used multiple sources of evidence. Besides studying industry reports and company documents, we conducted

\footnotetext{
${ }^{1}$ Lehtinen and Penttinen's thorough analysis of the evolution of the internationalization concept since the early 1960s revealed that "Internationalization of a firm concerns the relationships between the firm and its international environment, derives its origin from the development and utilization process of the personnel's cognitive and attitudinal readiness and is concretely manifested in the development and utilization process of different international activities, primarily inward, outward, and cooperative operations." (Lehtinen and Penttinen 1999, p. 13).
} 
qualitative, in-depth, semi-structured interviews with the founders, who were deeply involved with key decision-making processes in their respective firms from inception and with the start of international operation. These interviews were the most important for insightful first-hand information since these entrepreneurs are clearly the most knowledgeable sources of information about their venture creation activities (Shook et al. 2003). The founder of each firm was interviewed twice (average of $2.5 \mathrm{~h}$ the first time and $1 \mathrm{~h}$ the second time) over the course of 18 months from October 2005 to March 2007. After making clear to them the purpose of our study, we were allowed to study some of their company documents a month before the actual interviews. At their request, we had to send them the questions 2-3 weeks in advance so that they had time to reflect on them. During the interviews, we let the key informants talk freely about their venture formation and early international development. We asked our respondents to reflect upon their firms' formation along the four dimensions in the literature-driven conceptual framework and we tried not to influence their answers at this juncture. After the respondents had completed their recollections, we asked them another script of questions concerning topics not yet covered.

We began our analysis process by making detailed write-ups for each site. Although the write-ups were simply pure descriptions, they were central to the generation of insight because they helped us cope early in the analysis process with the often-enormous volume of data (Eisenhardt 1989). For each case, we used a pattern-matching technique to compare the empirically based pattern with the theoretical one. When an element of the literature-driven framework was not applicable, we sought an explanation directly from the interviewees as well as from the literature when possible. We also employed a cross-case synthesis technique in which we treated each individual case as a separate study and then assembled them for aggregate findings across the cases.

In order to achieve construct validity and allow for a well-rounded analysis of each case, we triangulated the data by exploiting a combination of multiple information sources: interviews with founders together with their brochures and websites as well as internal documentation provided by the companies. In addition to the firms' sources, we used secondary sources like industry reports, business articles, and enterprise information from the Vietnamese government's business information center. These data mainly were to corroborate and augment evidence from the other sources.

\section{Case write-ups}

Firm A (exporter)

\section{Firm}

Firm A is a growing Hanoi-based fashion and decor company, specializing in a wide range of high-end products, especially handbags, silk fashion, lacquer, ceramics, and bamboo. It not only distributes its own products but also makes customized products to order. Since its establishment (first as a boutique in 1998, then as a registered 
company in 2001 when the government issued a more entrepreneur-friendly enterprise law), it has been operating with a declared mission of promoting and introducing Vietnamese products to the world. Since then, it has built up business relationships with wholesalers from Japan, Australia, England, Germany, Italy, the United States, etc. Firm A's only entry mode to foreign countries is through exclusive distributors. It does not plan to use any other mode.

At the beginning, Firm A had only five people; none of them except the founder had any experience working with foreigners or in the fashion and decor industry, let alone any international market experience. The firm sold both standardized and customized products. It did not have a factory but collected goods from its subcontractors, most of which were small family businesses, when it had orders from overseas. No high-tech was involved. All of its products were made by hand in traditional ways. The firm had low risk preference (it only produced after receiving orders and only looked for exclusive distributors) and an average degree of innovativeness, pro-activeness, and competitive aggressiveness.

The network was very small when the firm was founded but grew along with the development of the firm. Now the company has established a large production network of more than 50 workshops with about 700 part-time and full-time employees. At present, all of Firm A's administrative staff (about 25 people) have been provided with business and technical training directly by the founder, who is now a professor of international entrepreneurship at a university in the US, and they have gained international experience through working with foreign customers.

\section{Founders/managers}

Firm A was born when the founder quit his previous company, a handicraft firm, which he had co-founded in 1995. At that time, he was in his mid-20s, had already gained his BS in Management, and was pursuing an American MBA program, which was held partly in Vietnam and partly in the US. Now he has obtained his DBA degree, also from a US university, and is working as a professor of international entrepreneurship in the US besides running Firm A from overseas. Before founding Firm A, he had never been abroad although he had been working with foreigners who came to work in Vietnam. On the other hand, he did not have technical experience in the fashion and decor business, but he chose this market niche because of its potential for higher returns. When asked why he set up this firm, he responded that the major goals were to experiment with what he had learned at business school and also to satisfy his desire to help the poor by creating jobs for them and to revitalize traditional craft villages.

\section{Industry}

The apparel and accessories industry is mature and extremely competitive with a high degree of internationalization. This volatile industry is specially dependent on consumer confidence, with consumers quick to cut their spending on non-essential items such as clothing when the economy gets tight. Therefore, suppliers have to compete bitterly on prices, causing a long-term shift in supply away from richer nations toward low-price labor markets such as Vietnam. 
On the demand side, there has been a strong global growth rate since 1998 (when Firm A was taking shape) thanks to the expansion of the European market and the improvement of distribution networks (Datamonitor 2003) (Table 2). Firm A certainly enjoys the increasing international demand, but it virtually does not have a market in Vietnam because the company's focus is on high-end products, and Vietnamese consumers simply cannot afford these goods.

\section{Socio-economic infrastructure}

At the time Firm A was founded, email and the Internet were very expensive and strongly censored in Vietnam. Hence, the firm mostly communicated in the traditional way for some years until email and the Internet became cheaper and more popular. Advances in production methods are not exploited by the firm either. This is because the firm advocates hand-made products and relies on the skills of its workers rather than any other factor. Since the firm only produces to orders, it is not concerned with modern logistics methods. However, Firm A acknowledges that cheaper and better transportation facilitates the business, but it does not see this as a decisive factor. On the other hand, the firm sees reduction in trade and investment barriers as good and bad at the same time: good because it can reduce prices, but bad because it makes it easier for other firms to go international. When the firm was founded, the manager did not see Vietnam's international economic integration process as a hindrance or motivator simply because of the reason why he had created the firm. Finally, any development in the international financial market is not felt by the company as it only uses traditional payment methods and does not intend to seek international investment capital.

Firm B (exporter)

\section{Firm}

Firm B was established in 1994 as a cashew nut collector from local farmers in Binh Duong province because it was able to take advantage of some preservation and processing methods that ordinary farmers could not owing to their lack of capital and organization, although the firm did not invent any technology. Just a year later, it started exporting directly to China. The company decided to export because the managers saw their friends making more profits by doing so. In addition, these friends referred their customers to the company because they could not collect enough cashew nuts for their customers. Since then, the company has been operated

Table 2 Textiles, apparel, and luxury goods market value (\$ billion) (source: Datamonitor 2003)

\begin{tabular}{lll}
\hline Year & \$ Billion & Growth \\
\hline 1997 & 807.67 & n/a \\
1998 & 824.07 & $2.0 \%$ \\
1999 & 880.50 & $6.8 \%$ \\
2000 & 911.59 & $3.5 \%$ \\
2001 & 964.20 & $5.8 \%$ \\
GAGR, 1997-2001 & & $4.5 \%$ \\
\hline
\end{tabular}


in the same fashion by ten people within the same family. Its strategy has been to work with some close customers. However, from 2007 on, the company is looking for more opportunities in neighboring countries as well as in Europe since, Vietnam's cashew output has been dramatically increasing every single year thanks to its aggressive expansion of cashew plantation areas and improvements in processing facilities.

\section{Founders/managers}

This private enterprise has been run as a family business where six brothers and relatives, aged between 20 and 50, share in managing the business and make group decisions. None of them has taken any business training courses. Before opening the business, they were all farmers without any international experience.

\section{Industry}

According to the Vietnam Chamber of Commerce and Industry, Vietnam's cashew industry has been growing quickly over the last 10 years, thanks to a combination of expanding areas, improving strains, and the developing processing industry, and can fully exploit the opportunities presented by international integration. In 1980, for example, cashew plantation areas occupied only 30,000 ha, but by 1996, this increased 250,000 ha and the total cashew production was 122,070 tons24,000 tons of which were exported for US \$122,070 million (Nguyen 1998). In 2004, cashew nuts became Vietnam's fourth-largest export item (Vietnam Business Forum 2004). By 2006, Vietnam bypassed India to become the world's largest cashew exporter (Agroviet 2006). Despite the dramatic growth, supply still lags far behind demand. This explains why companies like Firm B report that they almost never have difficulty in locating good foreign customers. The challenge is to collect enough supply and competition, for the export of cashew exists strongly among private companies.

\section{Socio-economic Infrastructure}

Firm B does not use any modern ICT means and does not care about production methods as it only collects raw cashews for export. Moreover, the firm is not aware of any advance in international logistics although it acknowledges that better transportation can make business easier. On the other hand, it considers itself too small to enjoy or suffer from any trade and investment barriers and believes that the strong market demand can offset all other factors. Finally, any development in international financial markets is not felt by the company as it only uses traditional payment methods and does not intend to seek international investment capital.

Firm C (importer)

\section{Firm}

Based in Ho Chi Minh City, Firm C is now active in three different industries: cosmetics, food additives and flavors, and orchids. The company started out in 1994 
as an exclusive distributor for a Canadian cosmetic firm. Via different distribution channels, such as dermatologist offices, pharmacies, cosmetic shops, beauty salons, and supermarkets, the company reached all major cities in Vietnam just within 2 years. In 1997, it established a skin care center to study and test cosmetic products before distribution in order to ensure customers' satisfaction. This center has become a research center for the treatment of skin disorders and cosmetic-related health problems. In 2003, it became the official distributor for a German company specializing in skincare products. In 1996, Firm C established its food additives and flavors department for Vietnam's emerging food processing industry. It also opened a laboratory to study applications of food additives and flavors to final products such as ice creams, beverages, confectioneries, and so on. This laboratory is also responsible for the company's after-sale services and technical training for its employees. So far, Firm $\mathrm{C}$ has been the official distributor of a Malaysian firm, two French firms, and a Chinese firm. Most recently, it started to become involved in growing and distributing orchids in 2003.

Firm C first employed 20 people, none of whom had any international experience. The company believes that prior international experience is not necessary since it is a domestic distributor, and the founder suffices to deal with foreign partners. These employees did not have any technical experience in the trade either because cosmetics were something very new to Vietnam at the time. The company considers marketing experience to be more important than technical experience since the technical experience of the abovementioned suppliers is enough. Nevertheless, the foreign partner, together with one of the founders, who is a medical doctor, has been providing routine training through internal workshops. Now the number of employees has doubled to take care of other product lines as well.

\section{Founders/managers}

The company was founded when the founder was in his early 40s. Prior to setting up his own company, he had had over 10 years' experience working for a state-owned textile factory as a technical officer after obtaining his BS degree in mechanical engineering. His wife, who was in her mid-30s and a professor at a medical university at that time, also took an active role in forming and running the firm. Since the company's initial focus was on skincare products, her medical background was a great asset. Before long, she quit her job at the university to devote her time totally to the firm. By the time the company was formed, neither of them had ever been abroad, but they had some family ties with relatives who had fled to North America when the Southern Vietnamese regime fell in 1975.

\section{Industry}

By the time Firm C was born, the international skincare market had experienced a slowdown with a compound annual growth rate of 4.6\% between 1993 and 1997 (Tenerelli 1999) but the skincare market in emerging economies experienced robust growth. This is because the consumption of skincare products, like that of any other non-essential consumer goods, is greatly determined by the amount of disposable income. According the United Nations Development Programme statistical data at 
http://www.undp.org.vn/economics/stat.htm, Vietnam's economy experienced a dramatic improvement during 1992-1997 with a strong growth rate of over $8 \%$. This, together with the fact that Vietnam has a massive consumer base of over 80 million people, whose demographic profile is very young and predominately female, makes Vietnam a very attractive market for cosmetic products. Therefore, it is not surprising that the Vietnamese skincare market enjoyed a double-digit compound annual growth rate between 1993 and 1997 (Bucalo 1999) (Table 3).

\section{Socio-economic infrastructure}

As a distributor only, the firm is not concerned about production methods. Furthermore, improvement in international transportation and logistics can lower market price, create more competitors, and may even enable its customers to import the goods directly without going through the firm. As for trade barriers, Firm C prefers high barriers because the barriers can depress competition in domestic markets. Finally, any development in international financial markets is not felt by the company, as it only uses traditional payment methods and does not intend to seek international investment capital.

Firm D (importer)

\section{Firm}

Founded in Hanoi in 2004, Firm D has a business license to operate with a wide range of activities from designing equipment and supplying materials for paper mills, trading electrical equipment, to organizing trade fairs and public relations activities for other businesses. Since then, the company's main business has been

Table 3 Skincare sales in Asia-Pacific region (US \$ billion) (source: Bucalo 1999)

\begin{tabular}{lrrrrrr}
\hline Category & \multicolumn{1}{c}{1993} & \multicolumn{1}{c}{1994} & \multicolumn{1}{c}{1995} & \multicolumn{1}{c}{1996} & CAGR \\
\hline Australia & 180.3 & 217 & 227.1 & 260.2 & 258.6 & $9.4 \%$ \\
China & 942.7 & $1,053.9$ & $1,281.9$ & $1,627.4$ & $1,953.1$ & $20 \%$ \\
Hong Kong & 26.9 & 33.1 & 40.2 & 48.4 & 56.9 & $20.6 \%$ \\
India & 54.7 & 77.7 & 97.9 & 121.6 & 147.2 & $28.1 \%$ \\
Indonesia & 0.4 & 0.4 & 0.4 & 0.4 & 0.3 & $-6.9 \%$ \\
Japan & $5,363.9$ & $6,287.1$ & $6,494.6$ & $6,528.1$ & $6,497.6$ & $4.9 \%$ \\
Malaysia & 63 & 73.9 & 84.9 & 94 & 84.4 & $7.6 \%$ \\
New Zealand & 66 & 81.5 & 90.5 & 108.8 & 103.8 & $12.0 \%$ \\
Pakistan & 24.9 & 31.8 & 35.4 & 40.3 & 43.7 & $15.1 \%$ \\
Philippines & 128.3 & 161.6 & 166.5 & 184.6 & 160.4 & $5.7 \%$ \\
Singapore & 6.6 & 8.3 & 9.7 & 10.9 & 10.3 & $11.8 \%$ \\
South Korea & $1,312.7$ & $1,426.5$ & $1,503.8$ & $1,448.1$ & $1,295.9$ & $-0.3 \%$ \\
Taiwan & 563.9 & 601.8 & 599.3 & 615 & 596.2 & $1.4 \%$ \\
Thailand & 266.3 & 290.6 & 313.5 & 325.3 & 251.4 & $-1.4 \%$ \\
Vietnam & 7.3 & 8.2 & 9.8 & 11.7 & 13.1 & $15.7 \%$ \\
Total & $9,007.9$ & $10,353.4$ & $10,955.5$ & $11,424.8$ & 11,473 & $6.2 \%$ \\
\hline
\end{tabular}


supplying scrap/waste paper as raw material for domestic paper mills. At first, it worked with domestic scrap paper suppliers, but just 5 months after its establishment, it sought foreign suppliers for higher profit margins. Now it imports scrap paper directly from Australia, Singapore, Taiwan, and China to sell to Vietnamese paper and pulp factories. The company only looks for foreign suppliers when it has signed contracts with domestic buyers whose needs and requirements may differ significantly, so its every transaction is a stand-alone one and the company does not yet feel the need for a stable supplier. It is also trading electrical equipment but has not tried to work with any foreigners in this area. The company wants to remain small, as it only targets high-volume transactions with big customers. When asked if it plans to become involved in outward internationalization, the company responded that it is contingent on the opportunity (in any trade lead) the managers discover, as they do not plan too far ahead, and their sole objective is profit.

\section{Founders/managers}

Firm D was established by a married couple and three women. None of them had worked in the paper industry before. The couple, both still in their mid-20s, are the major decision makers (the husband is the president and the wife is the managing director and chief accountant), while the others just contribute capital. When the firm was set up, the president had obtained his BS in business administration and had had 5 years' experience working for a Taiwanese electrical company and for Vietnam Tea. Although the managing director had not had any international business experience, she had obtained a BA in English. Nevertheless, neither of them had ever been abroad. The reason why they entered the paper business was because the managing director's father had been in the trade for almost 30 years, so it was relatively easy for them to find buyers.

\section{Industry}

Despite the increasing consumption volume of paper products, which includes household and sanitary paper, newsprint, printing and writing paper, and recycled paper, the global market of paper products has not performed well in recent years because of falling prices (Datamonitor 2005) (Table 4). Additionally, paper product companies have to face higher production costs as they are under tough pressure to comply with mounting environmental regulations, including specific measures with respect to air emissions, wastewater discharges, solid and hazardous waste management, site remediation, and forestry operations. Therefore, the production of paper products is being shifted to developing countries. In fact, Vietnam's paper industry has reported an average production growth of $17 \%$ per year over the past 20 years, reaching about 880,000 tons in 2005, 135,000 tons of which were exported (Hong Duong 2005). As a result, demand for raw materials soared, while there was a serious lack of supplies in Vietnam. According to Hanoi Trade and Consultancy, scrap paper collected in Vietnam is of low quality because it has been recycled too many times and prices are high. Therefore, imported scrap paper makes a lucrative business. 
Table 4 Global paper product market during 2000-2004 (source: Datamonitor 2005)

\begin{tabular}{lllll}
\hline Year & Million tons & Growth in volume & \$ Billion & Growth in value \\
\hline 2000 & 320.7 & - & 241.3 & \\
2001 & 316.4 & $-1.4 \%$ & 237.7 & $-1.5 \%$ \\
2002 & 324.4 & $2.5 \%$ & 237.4 & $-0.1 \%$ \\
2003 & 331.5 & $2.2 \%$ & 238.6 & $0.5 \%$ \\
2004 & 339.0 & $2.3 \%$ & 243.2 & $1.9 \%$ \\
CAGR, 2000-2004 & - & $1.4 \%$ & & $0.2 \%$ \\
\hline
\end{tabular}

\section{Socio-economic infrastructure}

Because Firm D wants to remain as a trader only, it is not concerned about improvement in production methods. Like Firm C, Firm D would not be happy if international transportation and logistics became better because it believes that the improvement can lower market prices, create more competitors, and may even enable its customers to import the goods directly without going through the firm. In addition, Firm D only imports when it has guaranteed orders from domestic buyers. As a pure trader, the firm does not care much about what goods or with whom it trades as long as it can make a profit. It explains why the imposition or reduction of barriers can only have an impact on the kind of goods the firm trades, not its decision to go international early on. Finally, any development in international financial markets is not felt by the company, as it only uses traditional payment methods and does not intend to seek international investment capital.

\section{Cross-case analysis}

In this section, we cross-compare the cases and present the results in a tabular form in which each and every company is compared against a typical firm depicted by the literature-driven conceptual framework. By doing this, we can reveal which expected motivators apply to Vietnamese born-global firms and which do not.

Firm resources and capabilities

Our cases did not support the proposition that only firms of a relatively bigger size in terms of the number of employees are able to internationalize early. Three of the four firms studied had fewer than ten employees at the time they internationalized. The one with the fewest employees (Firm A) was the one to internationalize earliest. Moreover, three out of the four firms did not have any prior international market knowledge - let alone any superior international market knowledge over that of other firms. Nor did they have any access to international business networks. Our interviewees shared the same view that they did not gain any international market knowledge unless they actually engaged their companies in international trade and that they did not need to experiment with other companies (e.g., working for internationalized companies or the like) to start their born-global firms. This led us to 
believe that neither prior international market knowledge nor access to international networks is necessary for firms to embark on early internationalization.

Furthermore, neither a unique product factor nor high technological innovativeness as a factor was evident in our cases. Firms A, B, and D only trade generic products. Firms A exports standardized hand-made apparel products and markets them with a slogan such as that buying their products means helping indigenous Vietnamese-i.e., its marketing emphasizes manual labor, not technology. Firm B exports cashews collected from local farmers. Since demand for cashews is much higher than supply, the company focuses its efforts on securing a stable supply from local farmers. Nevertheless, its access to the preservation and processing technology that local farmers are unable to obtain due to their lack of capital and organization contributes to the firm's success as a cashew collector. Firm D imports scrap paper for domestic paper mills. Obviously, this type of product is not unique, nor does it require any technology.

The only firm that trades somewhat non-generic products is Firm C, an importer of cosmetics. As the firm imports to redistribute, it does not need to be technologically innovative; rather, this is the job of its suppliers. However, the very nature of the cosmetic industry - where brand name is the make-or-break factorrequires Firm $\mathrm{C}$ to emphasize the product's uniqueness. From these four businesses, we can see that whether product differentiation and technological innovativeness are important depends on the industry.

The high entrepreneurship orientation of a firm - i.e., having autonomy and highrisk preference as well as being innovative, pro-active, and competitively aggressive - is listed in the literature as a "push" factor for its establishment as a born-global firm. The literature categorizes this as a collective trait of the firm. However, our cases are small groups of people who follow their leaders rather than doing business their own way, so the trait, if it is present at all, is irrelevant to how the staff behaves, except in the case of the decision makers with regard to the forming of internationalization strategy and its timing.

In short, firm resources and capabilities did not play a role in motivating our cases to internationalize when they were set up.

\section{Founder/manager characteristics}

The age factor did not seem to matter in our cases because the founders of the firms studied were of various ages, ranging between 20 and 50 at the time they founded their global start-ups. In addition, a high educational level has been noted in the literature as a driver because it enables entrepreneurs to discover international business opportunities. Therefore, focusing solely on the education level of these founders, most of whom have at least a bachelor's degree, we are likely to presume that their high education level drives them to undertake early internationalization. Interestingly, our interviewees denied this, while arguing that the Vietnamese educational system ill-equips people with the knowledge and skills necessary to work in international environments. They said it certainly does not take university study to notice that most Vietnamese cannot afford high-end, hand-made apparel products, that cashews are much higher-priced abroad, that cosmetics from first- 
world countries are preferred to those from less-developed countries, and that Vietnamese paper mills are hungry for input materials.

All but one of the founders of the firms studied had never founded any other business before establishing these firms, and they literally had no experience in the industries of their choice. This implies that they must have had high entrepreneurial inclinations. The literature acknowledges this factor but adds to it global visioni.e., a geocentric orientation with a positive attitude toward international activities as a result of a perception of low risks. This aspect does not apply to our cases. Our interviewees had a neutral attitude toward international activities when it came to comparing domestic operations versus international ones, although they saw the latter as generally more risky than the former. They insisted that international involvement was a better choice for their products, but not necessary. Thus, if they chose to trade other products, they were very flexible in switching products if others made more profit.

At the onset, only the founders of the two exporters had gained some experience working with foreigners within Vietnam only. This may or may not count as international experience; the literature, however, only seems to consider active involvement in international trade as international experience. The founders' experience working with foreigners in Vietnam did not help the firms to develop foreign strategic partners and to speed up foreign sales after start-up because the firms' actual partners do not come from the same countries as those of the foreigners the founders used to work with prior to establishing their firms.

One's business and personal network is long known for playing a vital role in doing business in Asia, in general, and in Vietnam, in particular. Our interviewees confirmed this and added that one cannot do business in Vietnam without the right network. However, lacking an international business and personal network did not deter them from setting up their international new ventures. Among the founders of the four firms, only the founders of Firm D had a prior relationship with foreign businesses through family ties that then helped the firm locate its initial suppliers from abroad. The founder of Firm A had some foreign friends who used to work with him before he spun off to found this firm, but he said these people did not form the right network for Firm A's business. The founders of Firms B and D were not in any international network, so they had to develop one while moving along their internationalization path. Interestingly, they did not see it as a disadvantage at all because their particular businesses rely on good domestic networks rather than international ones. Therefore, we can infer that an international network is helpful but not a reason for entrepreneurs to form their born-global firms.

To sum up, the founders of Vietnamese born-globals do not possess the characteristics of a typical born-global founder portrayed in the literature, so we cannot say that those characteristics induce Vietnamese entrepreneurs to form their born-global companies.

\section{Industry structure and attributes}

All four firms have been enjoying favorable market conditions on both the demand and supply sides. Our interviewees asserted that good market conditions determined their choice of products and who they traded with. At the time the firms were 
founded, they did not face much competition from other local firms because they were among the few who were able to supply the goods, while their chosen industries had been experiencing robust growth with positive forecasts and high degrees of internationalization. The market for Firm A's high-end apparel products has been negligible in Vietnam because of the Vietnamese low-income level, but increasingly large in developed countries because of their shift in industrial focus. As for Firm B, strong international demand for cashews has made it much more profitable for the firm to sell abroad than to sell domestically. Firm C's cosmetic products from first-world countries as well as food chemicals from more technologically advanced countries have been highly sought after in Vietnam. In addition, Firm D has been taking good advantage of Vietnamese paper mills' severe shortage of raw materials to make profits by importing scrap paper. The managers of these four firms admitted that they were not the first to internationalize, though. They were greatly motivated by the success of other companies in going international.

Regarding buyer preference, it is homogenized only for Firms B and D's products because the products are raw materials. Meanwhile, buyers in Firms A and C's industries have very different preferences. In fact, sales of high-end apparel products and cosmetics rely on consumers' disposable incomes, which vary greatly between Vietnam and the countries with whom our cases trade. Hence, we cannot conclude that these firms internationalized because of the reduced transactions costs of foreign market expansion and simplified product development and positioning in foreign markets as a result of homogenized buyer preference.

\section{Socio-economic infrastructure}

In contrast to what is generally believed, our interviewees do not believe that development in socio-economic infrastructure induces them to internationalize at or near inception. Advances in information and communication technology (ICT) may facilitate businesses, but this did not play a role in the formation of all four firms. When Firms A, B, and C became born-global, ICT was overwhelmingly costly in Vietnam and the government heavily censored all information, especially information from abroad. That is why those firms relied on relationships and word-of-mouth to conduct their business with foreigners. In fact, Firms C and D (both are importers) prefer that situation, as it erects high barriers to entry and allows the firms to make abnormal profits from imperfect information.

Likewise, cheaper and better international transportation and logistics may facilitate businesses to internationalize, but our cases did not really need it. The founders of Firms A and B (both are exporters) agree that it helps them reduce prices, but it was not a decisive factor for them to decide to go international since the demand from abroad was strong enough to offset transportation costs. The founders of the other two firms are actually concerned about improvements in international transportation and logistics, as they believe that these improvements can lower market prices, create more competitors, and even may enable their customers to import the goods directly without going through their firms.

Advances in production methods are not a motivator either. Firm A advocates hand-made products and relies on the skills of its workers rather than any other iㅡㄹ Springer 
factor, while Firm B does not care about production methods, as it only collects raw cashews for export. For the two importers, this factor is obviously irrelevant.

The reduction of trade and investment barriers as a result of international economic integration is not seen by our interviewees as a pulling factor. They all said that they would go international anyway-whether there was any reduction in trade barriers or not - because the market conditions were good enough for them to do so. Additionally, they all feel that their companies are too small to be impacted by external investment barriers because they can mobilize enough capital from their family. Furthermore, any development in international financial markets has not been felt at all by these four firms because they only use traditional payment methods and do not intend to seek international investment capital. Therefore, both advances in financial markets and access to international investment capital are irrelevant factors.

\section{Summary of findings}

In order to draw conclusions on what played a role in the formation of Vietnamese born-globals, Table 5 shows which of the factors motivating a typical firm depicted by the literature-driven conceptual framework to become born-global were present at the time our cases started internationalizing.

\section{Discussion}

The argument that firm resources and capabilities push entrepreneurs to set up their born-globals was not supported by our cases. To find an explanation for that, we need to look at Vietnam's specific context. The reason why the four firms we studied internationalized when they had very few employees lies in the Vietnamese autocratic management style where the head dictates and others follow. This management style, as confirmed by the founders we interviewed, has roots in Vietnamese culture, which emphasizes social hierarchy and the legacy of Vietnam's long-time implementation of a centralized economy system. Most Vietnamese do not want to do tasks belonging to people of a higher rank (because they do not want to take the responsibility they have not been given) or a lower rank (because doing so would downgrade their social image). Since employees are accustomed to doing what they are told and prefer not to take charge or interfere with their boss's business, founders are usually left to their own devices even if they want to manage the firm democratically.

Therefore, one might expect that founder/manager characteristics are critical drivers of Vietnamese born-global formations. Interestingly, our cases gave little support for that proposition. Age, experience in founding businesses, industrial and technical experience, international experience, and entrepreneurial inclination with high global vision were not present in the firms studied. This can be explained by the entrepreneurial culture of Vietnamese business people, who tend to emphasize shortterm net profits, rather than long-term business growth (Swierczek and Thai 2003). Moreover, Vietnamese entrepreneurs have a tendency to plan short-term activities in order to maintain their survival (Enno and Hidde 2000). As a result, they are not 
inclined to any particular industry; rather, they go wherever they see there are profits to be made. Agreeing with those points, our interviewees added that they were equally interested in staying purely domestic should the profits be the same as otherwise.

The theory that a firm's network and international market knowledge will push it to be born-global did not apply to our cases either. At the time the firms internationalized, their staff had virtually no international market knowledge nor access to any international networks. Firms A and D were established when the founders were just fresh graduates, while the other firms were formed just when the US trade embargo on Vietnam was lifted. Why did this lack not hinder the firms as they embarked on international trade? It was because almost all Vietnamese private firms were in the same situation, lacking information and contacts with the outside world, as a result of poor access to quality information channels (Webster 1999) and Vietnam's closed economy. Consequently, internationalizing firms acquire these resources as they go along. While doing so, they face enormous obstacles from Vietnam's unsupportive and uncertain business environment (Benzing et al. 2005).

If Vietnam's socio-infrastructure is too poor to pull firms, and the firms do not have the resources and capabilities to push, and their founders/managers do not have the characteristics identified in the existing literature, how was it possible for our cases to internationalize so early? First, we need to understand why Vietnamese firms are formed. Vietnamese entrepreneurs are significantly motivated by challenge and achievement (Swierczek and Thai 2003). They form businesses to provide jobs for themselves and family members, to gain public recognition, and to prove they can successfully run a business of their own (Benzing et al. 2005). While the idea of opening a business is taking shape, they look everywhere for opportunities that can provide quick profits for survival. Those who see more profits from international trade than domestic trade will engage in international trade and vice versa. Our cases strongly support the proposition that market conditions and industry pressure pull firms to internationalize. Perhaps that was the only choice for them to start their own business, given what they encountered during their market search for business opportunities. When asked about internationalization direction, our interviewees said they would not stick to one industry or any particular internationalization mode and might even de-internationalize if doing so yielded more profits. That is the reason why we believe that the founders do play a critical role in born-global firms' formation, even though the founders of the firms studied do not have the characteristics listed in the literature. Since they manage their businesses autocratically, they are the powerhouse that determines their firms' development direction. To form born-global firms, the entrepreneurs must be pro-active and risk taking. This concept relates to the entrepreneurship orientation of the founders alone, rather than to the firms, as noted in the literature.

\section{Concluding remarks}

With this multiple-case study, we have made three contributions to the emerging born-global literature. First, we found out that the Vietnamese born-globals we studied were formed because of the entrepreneurs' leadership desire together with 


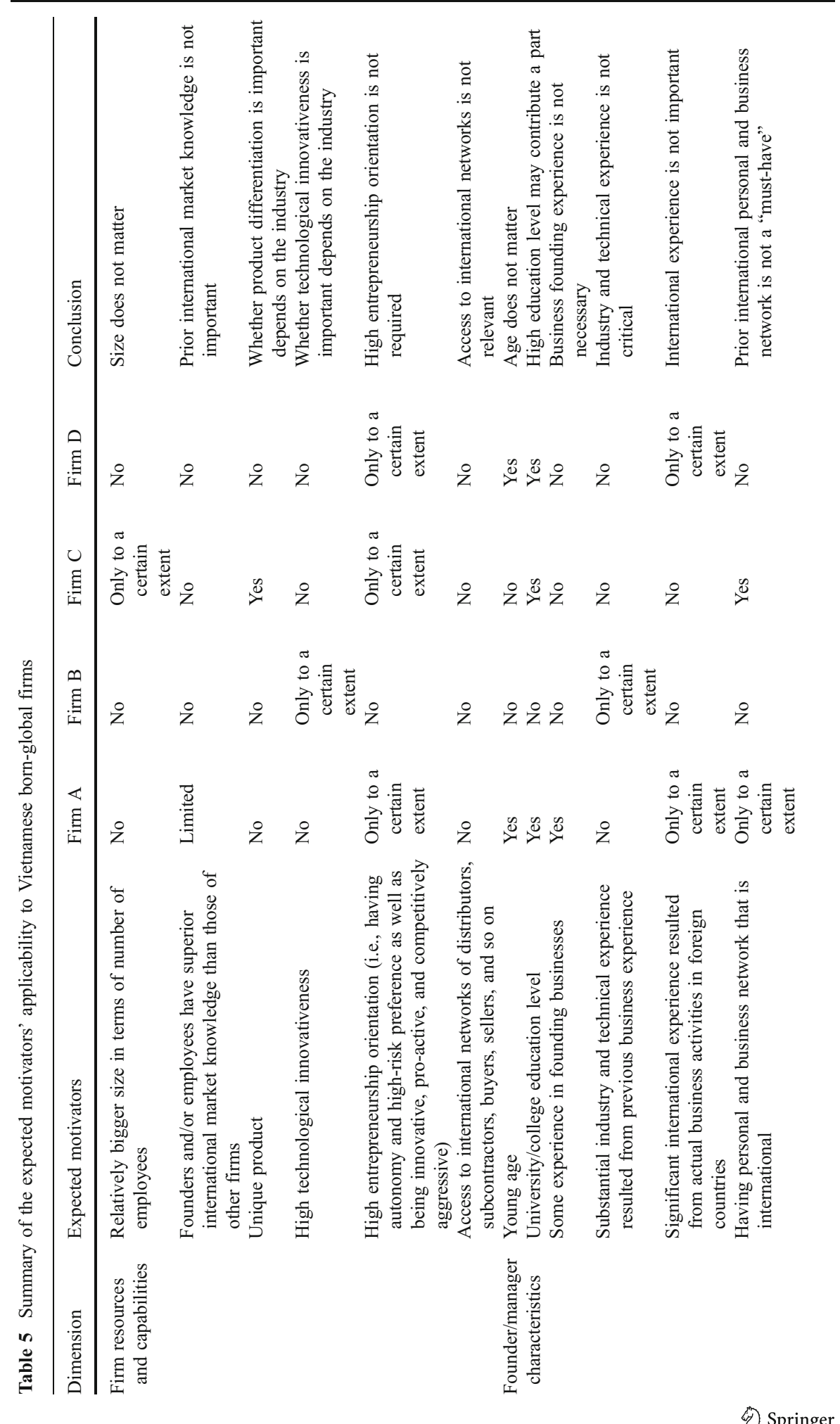




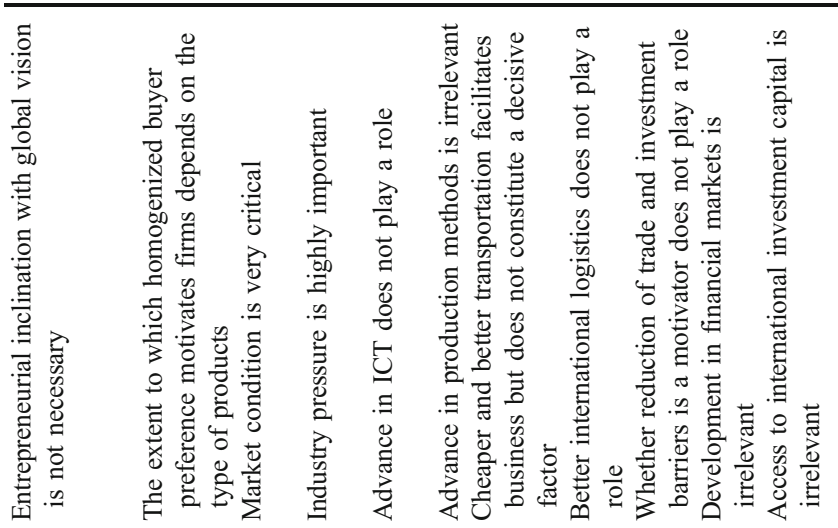

z

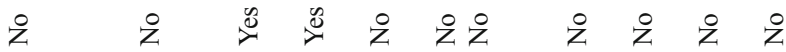

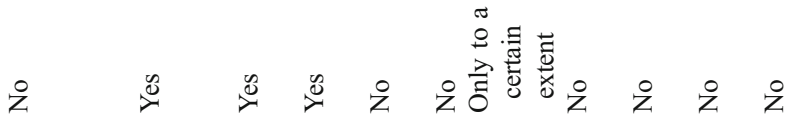

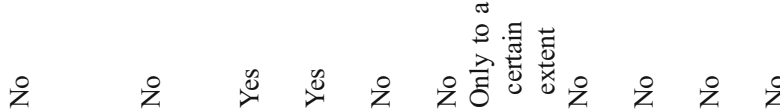

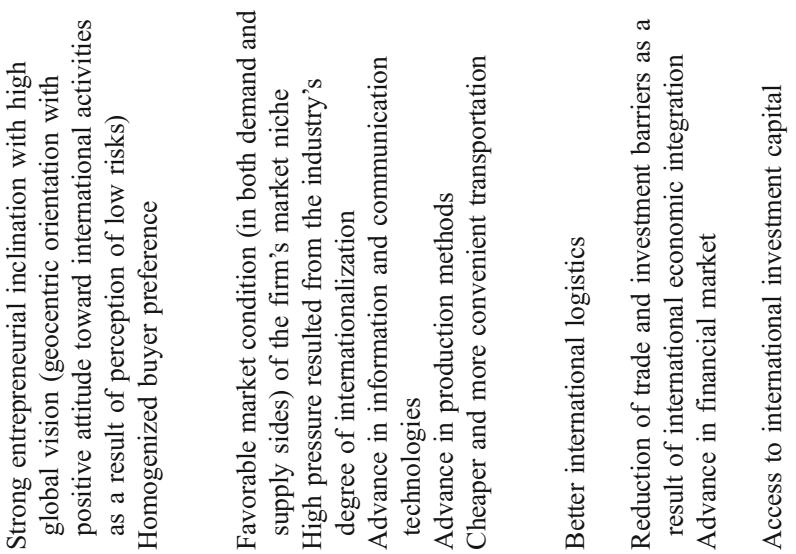

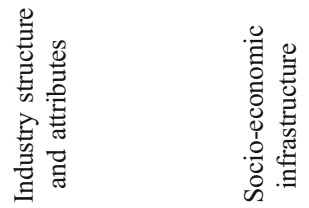


their need for higher short-term profits. Second, market conditions both at home and abroad and the degree of internationalization of the industries where they found their business opportunities influenced the founders' decision as to whether to set up an importing or exporting firm. Third, the context of Vietnam could explain the reasons why many motivators found in the existing literature did not apply to our cases.

The findings have certain implications for both entrepreneurs and policy makers in Vietnam. For the entrepreneurs, an accurate assessment of current market conditions as well as changes in market conditions in the short run is critical to make sure that their decision to embark on international business at an early age and decision on internationalization direction can yield instant results to sustain the business. Therefore, they must have access to effective information channels and possess sufficient analytical skills to treat the data they gather.

However, Vietnamese managers operate with far less information than managers in other countries would tolerate. They face serious shortages of key information about products, markets, technologies, trends, etc. simply because up-to-date and high-quality information sources are rare in Vietnam and managers' ability to search for information is restricted by such barriers as the strict state controls of all publishing and media, the high costs of accessing the Internet, and closed stack public libraries. Private SMEs are further handicapped because most of the limited information infrastructure in place was built to channel information and opportunities to state-owned companies. Most Vietnamese business people feel that stateowned enterprises always have priority access to the truly valuable information from their line ministries. In fact, information about key contracts is held internally by ministries and their enterprises with little access for outsiders. When potential buyers come to Vietnam to find trading partners, they are usually directed to state-owned enterprises as potential partners.

Hence, Vietnamese entrepreneurs should actively gather information and knowledge from various sources both within and outside Vietnam. Since Vietnam started implementing open-door policies in 1986, the government has gradually reduced the barriers that restricted its citizens from traveling abroad and contacting people in former enemy countries, especially Vietnamese refugees, so Vietnamese entrepreneurs can exploit such information sources as overseas Vietnamese communities, foreign market visits, trade fairs, and the Internet. They should also improve their knowledge of the international market by participating in industry forums, monitoring international market news, and perhaps following international management courses provided by internationally reputable institutions (many of which are free online, e.g., open-source courses provided by the Massachusetts Institute of Technology in the US). On the other hand, policy makers should come up with measures to help Vietnamese entrepreneurs. In the short run, they can provide Vietnamese entrepreneurs with references to quality market monitoring services, supports to attend foreign trade fairs, and training courses on international business. In the intermediate run, the government should reduce its media censorship and make Internet access more affordable by allowing more competition in the telecommunication sector. In the long run, the government should stop compelling higher education institutions to follow rigid government-approved curricula so that these institutions can develop curricula that provide students with what they need and not what the government wants to force into their heads. 
To complete our paper, we acknowledge that the case study method does not allow us to generalize our findings to all Vietnamese born-global firms, but it serves our purpose of exploring this phenomenon, which has never previously been investigated in the literature. If access and resources allow, future research may employ a quantitative method to validate our findings. Additionally, future studies may explore the internationalization path that Vietnamese born-globals follow and critical the success factors for them in doing so.

Acknowledgements We would like to thank the two anonymous reviewers and the editor for their constructive criticism as well as suggestions that helped us improve the quality of our paper. And we are especially grateful to our respondents who generously shared with us their detailed stories and insightful knowledge to make this research endeavor a success.

\section{References}

Agroviet (2006) Vietnam bypassed India to be the world largest cashew exporter [Viet Nam danh bat An Do de gianh vi tri xuat khau dieu hang dau the gioi] Information Center of Ministry for Agriculture and Rural Development. http://www.agroviet.gov.vn. Accessed 25 April 2006

Andersson P (2002) Connected internationalisation processes: the case of internationalising channel intermediaries. Int Bus Rev 11(3):365-383

Andersson S, Wictor I (2003) Innovative internationalisation in new firms: born globals - the Swedish case. J Int Entrepr 1(3):249-275

Aspelund A, Moen O (2001) A generation perspective on small firm internationalization: from traditional exporters and flexible specialists to born globals. Adv Int Market 11:197-225

Bartlett CA, Ghosbal S (1989) Managing across borders: the transnational solution. Harvard Business School, Boston

Baughn CC, Neupert KE (2003) Culture and national conditions facilitating entrepreneurial start-ups. J Int Entrepr 1(3):313-330

Bell J, Crick D, Young S (2004) Small firm internationalization and business strategy: an exploratory study of 'knowledge-intensive' and 'traditional' manufacturing firms in the UK. Int Small Bus J 22 (1):23-56

Benzing C, Chu HM, Callanan G (2005) A regional comparison of the motivation and problems of Vietnamese entrepreneurs. J Dev Entrep 10(1):3-27

Bilkey WJ (1978) An attempted integration of the literature on the export behavior of firms. J Int Bus Stud $9(1): 3$

Bloodgood JM, Sapienza HJ, Almeida JG (1996) The internationalization of new high-potential U.S. ventures: antecedents and outcomes. Entrepreneurship Theory Pract 20(4):61-76

Boter H, Holmquist C (1996) Industry characteristics and internationalization process in small firms. J Bus Venturing 11(6):471-487

Bucalo A (1999) Cosmetics and toiletries in Asia Pacific. Glob Cosmet Ind 164(3):32-36

Burgel O, Murray GC (2000) The international market entry choices of start-up companies in hightechnology industries. J Int Mark 8(2):33-62

Burrill G, Almassey S (1993) Electronics '93, the new global reality. Ernst \& Young's fourth annual report on the electronics industry. Ernst \& Young, San Francisco

Calof JL, Beamish PW (1994) The right attitude for international success. Bus Q 59(1):105-115

Carson D, Cromie S, McGowan P et al (1995) Marketing and entrepreneurship in SMEs: an innovative approach. Prentice Hall, Hertfordshire

Chetty S, Campbell-Hunt C (2004) A strategic approach to internationalization: a traditional versus a 'born-global' approach. J Int Mark 12(1):57-81

Datamonitor (2003) Global textiles, apparel \& luxury goods: industry profile. Reference Code: 01992147. http://www.datamonitor.com. Accessed June 2003

Datamonitor (2005) Global paper products: industry profile. Reference Code: 0199-2123. http://www. datamonitor.com. Accessed May 2005

Dichtl E, Koeglmayr H, Mueller S (1990) International orientation as a precondition for export success. J Int Bus Stud 21(1):23-40

Springer 
Eisenhardt KM (1989) Building theories from case study research. Acad Manage Rev 14(4):532-550

Enno M, Hidde S (2000) Planning behavior of small firms in Central Vietnam. J Small Bus Manage 38 (2):95-102

Etemad H (2004) Internationalization of small and medium-sized enterprises: a grounded theoretical framework and an overview. Can J Admin Sci 21(1):1-21

Evangelista F (2005) Qualitative insights into the international new venture creation process. J Int Entrepr 3(3):179-198

Ghoshal S (1987) Global strategy. Strateg Manage J 8(5):425-440

Hambrick DC, Mason PA (1984) Upper Echelons: the organization as a reflection of its top managers. Acad Manage Rev 9(2):193-206

Harveston PD (2000) Synoptic versus incremental internationalization: an examination of 'born global' and 'gradual globalizing' firms. Ph.D. dissertation at The University of Memphis. UMI Microform 9993820

Hong Duong (2005) Paper industry starved for modern technology. Vietnam Economic News OnlineThe Official Publication of The Ministry of Trade of Vietnam. http://www.ven.org.vn/view_news. php?id=5110. Accessed 7 September 2007

Hedlund G, Kverneland A (1985) Are strategies for foreign markets changing? The case of Swedish investment in Japan. Int Stud Manage Organ 15(2):41-59

Ibeh KIN (2003) Toward a contingency framework of export entrepreneurship: conceptualisations and empirical evidence. Small Bus Econ 20(1):124-141

Johnson JE (2004) Factors influencing the early internationalization of high technology start-ups: US and UK evidence. J Int Entrepr 2(1\&2):139-154

Katz JA, Safranski SR, Khan O (2003) Virtual instant global entrepreneurship. J Int Entrepr 1(1):43-57

Knight GA (2001) Entrepreneurship and strategy in the international SME. J Internat Manag 7(3):155-171

Knight GA, Cavusgil ST (1996) The born global firm: a challenge to traditional internationalization theory. Adv Int Market 8:11-26

Knight GA, Cavusgil ST (2004) Innovation, organizational capabilities, and the born-global firm. J Int Bus Stud 35(2):124-141

Knight GA, Cavusgil ST (2005) A taxonomy of born-global firms. Manag Int Rev 45(Special issue 3):1535

Knight G, Madsen TK, Servais P et al (2000) The born global firm: description and empirical investigation in Europe and the United States. Proc Am Market Assoc Chicago 11:104

Kobrin SJ (1994) Is there a relationship between a geocentric mind-set and multinational strategy. J Int Bus Stud 25(3):493-511

Kundu SK, Katz JA (2003) Born-international SMEs: BI-level impacts of resources and intentions. Small Bus Econ 20(1):25-47

Lehtinen U, Penttinen H (1999) Definition of the internationalization of a firm. In: Lehtinen U, Seristö H (eds) Perspectives on internationalization. Helsinki School of Economics and Business Administration, Helsinki, pp 3-19

Levitt T (1983) The globalization of markets. Harvard Bus Rev 61(3):92-102

Lumpkin G, Dess GG (1996) Clarifying the entrepreneurial orientation construct and linking it to performance. Acad Manage Rev 21(1):135-172

Madsen TK, Servais P (1997) The internationalization of born globals: an evolutionary process. Int Bus Rev 6(6):561-583

Manalova TS (2003) Small multinationals in global competition: an industry perspective. In: Etemad H, Wright R (eds) Globalization and entrepreneurship: policy and strategy perspectives. Edward Elgar, Northampton, pp 59-81

McAuley A (1999) Entrepreneurial instant exporters in the Scottish arts and crafts sector. J Int Mark 7 (4):67-82

McDougall PP (1994) Explaining the formation of international new ventures: the limits of theories from international business research. J Bus Venturing 9(6):469-487

McDougall PP, Oviatt BM (1996) New venture internationalization, strategic change, and performance: a follow-up study. J Bus Venturing 11(1):23-40

McDougall PP, Oviatt BM, Shrader RC (2003) A comparison of international and domestic new ventures. J Int Entrepr 1(1):59-82

Michel JG, Hambrick DC (1992) Diversification posture and top management team characteristic. Acad Management J 35(1):9-37

Moen O (2002) The born globals: a new generation of small European exporters. Int Mark Rev 19(2):156175 
Moen O, Servais P (2002) Born global or gradual global? Examining the export behavior of small and medium-sized enterprises. J Int Mark 10(3):49-72

Morris MH, Kuratko DF (2002) Corporate entrepreneurship: entrepreneurial development within organizations. South-Western College Publisher, Mason

Murtha TP, Lenway SA, Bagozzi RP (1998) Global mind-sets and cognitive shift in a complex multinational corporation. Strateg Manage J 19(2):97-114

Nguyen MC (1998) Integrated production practices of cashew in Vietnam. In: Papademetriou MK, Herath EM (eds) Integrated production practices of cashew in Asia. FAO Regional Office for Asia and the Pacific, Bangkok

OECD (1997) Globalisation and Small and Medium Enterprises (SMEs): synthesis report. Organization for Economic Co-operations and Development, Paris

Oviatt BM, McDougall PP (1994) Toward a theory of international new venture. J Int Bus Stud 25(1):4564

Oviatt BM, McDougall PP (1995) Global start-ups: entrepreneurs on a worldwide stage. Acad Manage Exec 9(2):30-43

Oviatt BM, McDougall PP (1997) Challenges for internationalization process theory: the case of international new ventures. Manag Int Rev 37(2):85-99

Oviatt BM, McDougall PP (2005) Toward a theory of international new ventures. J Int Bus Stud 36(1):2941

Perlmutter HV (1969) The tortuous evolution of the multinational corporation. Columbia J World Bus 4 (1):9-18

Pinney JK (1970) Process of commitment to foreign trade. Indiana Department of Commerce, Indianapolis

Porter ME (1990) New global strategies for competitive advantage. Plann Rev 18(3):4-14

Rasmussen E, Madsen T, Evangelista F (2000) The founding of the born global company in Denmark and Australia: sense-making and networking. Working Papers in Marketing, No. 25. Odense M, University of Southern Denmark

Reid SD (1981) The decision-maker and export entry and expansion. J Int Bus Stud 12(2):101-112

Rennie MW (1993) Born global. McKinsey Q 4:45-52

Reuber AR, Fischer E (1997) Influence of the management team's international experience on the internationalization behaviors of SMEs. J Int Bus Stud 28(4):807-825

Rialp A, Rialp J, Urbano D et al (2005) The born-global phenomenon: a comparative case study research. J Int Entrepr 3(2):133-171

Roberts EB, Senturia TA (1996) Globalizing the emerging high-technology company. Ind Mark Manage 25(6):491-506

Roth K (1995) Managing international interdependence: CEO characteristics in a resource-based framework. Acad Manage J 38(1):200-231

Räisänen JAS (2003) Evolution of internationalization theories related to the born global concept. Helsinki University of Technology, Helsinki

Sambharya RB (1996) Foreign experience of top management teams and international diversification strategies of U.S. multinational corporations. Strateg Manage J 17(9):739-746

Sharma DD, Blomstermo A (2003) The internationalization process of born globals: a network view. Int Bus Rev 12(6):739-753

Shook CL, Priem RL, McGee JE (2003) Venture creation and the enterprising individual: a review and synthesis. J Manage 29(3):379-399

Simpson CL Jr, Kujawa D (1974) The export decision process: an empirical inquiry. J Int Bus Stud 5 (1):107-117

Sullivan D, Bauerschmidt A (1990) Incremental internationalization: a test of Johansson and Vahlne's thesis. Manag Int Rev 30(1):19-30

Swierczek FW, Thai TH (2003) Motivation, entrepreneurship and performance of SMEs in Vietnam. J Enterp Cult 11(1):47-68

Tenerelli MJ (1999) The state of the skincare industry revealed. Glob Cosmet Ind 164(6):42-47

Vietnam Business Forum (2004) Cashew nut exports second in the world. Vietnam Chamber of Commerce and Industry (VCCI). May 22, 2004

Webster L (1999) SMEs in Vietnam: on the road to prosperity. Mekong Private Sector Development Facility (MPDF), Hanoi

Yin RK (2003) Case study research: design and methods. Sage, Thousand Oaks

Zahra SA (2005) A theory of international new ventures: a decade of research. J Int Bus Stud 36(1):20-28 